\title{
日本総合健診医学会の法人化にあたり，33 年の歴史を振り返って
}

\author{
日本総合健診医学会 \\ 理事長 田村 政紀
}

私は昭和 53 年 $(1978$ 年) にPL 東京健康管理セン 夕ー所長に就任し，日本総合健診医学会に個人正会 員として入会して以来 31 年になるが, 平成 9 年 (1997 年) 1 月には本学会第三代理事長に指名され 10 年間理事長を務め, 2007 年 1 月末に日野原重明先生 に理事長をバトンタッチした。本学会の創立および 創立後の 10 年間ぐらいの本学会の動きの詳細は, 先 輩諸先生方の記述に待つことにするが，私なりに本 学会の歴史を振り返ってみたい。特に平成 19 年 （2007 年）1月末に学会理事長を退任するまでの 10 年間は, 様々なことがあったので, 学会の歴史とし て残しておく必要があると思い記した。

\section{I . 創立から理事長就任の平成 9 年（1997}

\section{年） 1 月までの歴史}

\section{1. 自動化（総合）健診導入の夜明け}

我が国に自動化健診が東芝総合健診センターと PL 東京健康管理センターでスタートしたのは昭和 45 年（1970 年）であるが，導入のきっかけには，自 動化健診の情報提供と視察団の派遣があった。

Kaiser 財団が作った Automated Multiphasic Health Testing and Services（AMHTS）の内容が最初に日 本に伝えられたのは, 昭和 41 年 (1966 年) 9 月のリー ダーズダイジェスト日本版の記事「登場したオート メ健診」であった。昭和 42 年（1967 年） 2 月に愛知 県総合保健センターの岩塚徹先生が Oakland の KaiserのAMHTSを見学し，その内容を同年 4 月の日本 ME 学会において, カイザー健診の見学報告という テーマで紹介した。岩塚先生によるこの報告が本邦 医学界への AMHTS 情報の第一報であった。

1967 年 (昭和 42 年) 7 月 28 日に, 樫田良精先生が ME 国際会議の途次, Oakland の Kaiser Foundation Medical Center を訪問された。その時の訪問の様子 が樫田先生著の「臨床検査 50 年一医療の近代化をめ ざして」に記されていて，同行された三輪卓爾先生
と一緒に同所で Dr. Garfield と歓談されている写真 が掲載されている。その後東芝メディカル社長の岩 井喜典氏も見学され, 樫田良精先生と岩井喜典氏の 協力によって新しい AMHTS システムの健診施設開 設準備が進められ, 昭和 45 年 (1970 年) 5 月に我が 国最初の東芝総合健診センターがスタートした。

一方, 樫田良精先生や東芝グループとは関係なく 1969 年（昭和 44 年） 4 月に PL 医学部の村上圭司先 生 (現 PL 病院院長) と八坂敏夫氏（元本学会理事, 国際委員長)が世界医療施設見学のツアーに参加し, たまたま菅沼源二氏 (本学会理事, 精度管理委員長) とッアーで一緒になり, Kaiser の AMHTS システム を見学した。このことが縁で昭和 45 年 (1970 年) 12 月に PL 東京健康管理センターがオープンした。

東芝総合健診センターと PL 東京健康管理セン ターは, それぞれの理念で設立され発展し, 今日に 至っている。

\section{2.日本自動化健診医学会の創立}

昭和 48 年（1973 年）11月に，本学会は日本自動 化健診システム研究会として設立された。設立発起 人は, 樫田良精先生 (東大医学部), 日野原重明先 生 (聖路加国際病院), 飯田晶先生 (東芝中央病院), 藤間弘行先生（藤間総合病院）, 岩塚徹先生（愛知 県総合保健センター), 岩井喜典氏 (東芝メディカル 株式会社）の 6 氏であった。初代学会会長に樫田先 生が就任した。

創立の翌年（昭和 49 年 $(1974$ 年)）4 月に「自動 化健診システム研究会会誌」が創刊された。この創 刊号に樫田良精会長の発起人挨拶が載っている。日 本病院会や人間ドック学会において，「1974 年に日 本病院会予防医学委員会第 2 部会として日本自動化 健診医学会が発足」との情報が流れているが，完全 な䛊報である。日本病院会や人間ドック学会とは関 係なく，全く新しい考えで設立された学会である。 本学会が発足する経過や創立時の趣意を知る上で参 考になるので，少々長くなるが樫田先生の発起人挨 
拶を転載する。

\section{発起人挨拶}

ただいまご紹介いただきました樫田でございま す。発起人といたしましては, 東芝中央病院の飯田 先生, 東芝メディカルの岩井社長, 愛知県総合保健 センターの岩塚先生, 聖路加病院院長代理の日野原 先生, 藤間病院の藤間先生, それと私, この 6 人が 発起人になりまして, 本日の研究会のいろいろ準備 をいたしてまいりました。ただ今より私が代表いた しまして，従来の経過，設立の趣旨というようなも のを簡単にご説明いたしたいと思います。

この話はだいぶ前からございましたが，具体的に 設立発起人の打ち合わせ会をいたしましたのは 10 月 26 日でございました。さらに 10 月 31 日に発起人 の総会をいたしました。また細かい規則，その他実 行計画を検討するために世話人会を 11 月の 8 日，さ らに16日というようにたび重ねまして，本日のこの 設立総会にこぎつけたわけでございます。その間, 不慣れのため，あるいは非常にあわただしく準備い たしました関係から，皆さま方へのいろいろなご連 絡が大変遅くなりました。本日の会も非常にご多忙 の先生方が多いので，行きたいけれども予定がつ まっていてどうにもならないという方が多数おられ ましたことは，われわれ準備をいたしました者の不 手際として，ここに心からお詫び申し上げたいと思 います。また今日おいでいただきました先生方には いろいろ予定をお変えいただいて非常に無理してお いでになった方が多数あると思いますので，その点 厚く感謝申し上げたいと思います。

次にこの会の設立趣旨でございますが，趣意書と して私ども世話人がつたない文章を書きました。私 の話よりもこれを読ませていただいたほうがよいと 思いますので一読させていただきます。

「近年一般国民の健康に対する意識が向上し，在 来からの各種の集団検診のみではあきたらず，より 多面的で精密な人間ドックによる健診を希望する 人々が激増しました。そのため人間ドックの受け入 れ態勢が窮迫し，受診希望者の間に不満の声が高ま りました。幸いにも自動検査機器，コンピュー夕， システム工学を活用した新しい健診の手法 Automated Multiphasic Health Testing and Services (AMHTS) が米国において開発され，これがわが国 に導入されるやいなや, わずか 2,3 年の間に急速に 普及し，いわゆる自動化健診システムの施設が現在
すでに 26 を数えるにいたりました。自動化健診シ ステムの健全な発達は多くの受診希望者にとって喜 ばしいのみでなく, 健康保持, および健康増進を含 めた広義の包括医療を今後強力に進める必要のある 医療関係者にとっても一つの画期的な手段が与えら れたという意味で大いに望ましいことであります。

この新しい健診システムについての共通の問題点 を討議して, その進歩, 向上を図るため, 昨年来多 くの自動化健診センター関係者が会合を重ね，また 同一試料による化学検査のコントロールサーベイな ども施設間で行っておりましたが，最近外国のこの 種の施設団体との交渉もしげくなり, AMHTS 国際 会議が本年はロンドン, 明年はサンフランシスコ, 明後年はメキシコシティで開催されることになり， 3 年後には日本でとの要望が出されるまでにいたり ました。このような情勢からいまやAMHTSに関す る全日本の統一学術団体を設立して, この堅実な発 展に資する好機を迎えたと考える次第であります。 よって，わが国のすべての AMHTS 施設関係者を包 含し, これに関する各種の専門家, 学識経験者を加 えて学術団体”日本自動化健診システム研究会”を 設立いたします」というような趣旨でございます。

この内容について，今日お集まりの各方面のご専 門の先生方には，いまさら申し上げる必要もないと 思いますが, 外国の情勢は, ごく最近のところは読 んでおりませんが，少なくとも昨年ごろの資料によ りますと，世界で 200 以上のこの種の施設がすでに できております。しかし，その内容にはいろいろな 形がございますし，また，大多数の施設はアメリカ にあって，ヨーロッパはまだ少しでございます。そ れから南半球ではオーストラリアに，2 年前に私が 国際会議で行きましたときに三つの施設が一応ござ いました。どのくらい世界で普及しているか, 形式 が人間ドック的なものと，自動化的なものと，その 中間をいくようなものとがいろいろあるようでござ いますので，はっきりした数はまだ摑めておりませ ん。先生方の中でこれについて詳しい方がおられま したら，本研究会でいろいろご報告いただきたいと 思っております。私の申し上げた設立趣旨，設立の 必要性はもちろん皆さん方はっきり認めていらっ しゃいますが，この会はわれわれ発起人が勝手にい ろいろなことをやるのではございません。こういう 研究会ができた上は会員におなりいただいた先生方 皆さんの意思で決定した線にそって進めていきたい と思います。会員が自分たちでこの会を育てること 
が大切でございます。われわれ世話人はこの設立準 備をいたしましたが，今後どうか皆さま方のいっそ うのご協力をお願いしたいと思います。

設立総会の最初にあたりまして一言ごあいさつ申 し上げました。どうぞよろしくお願いいたします。

（日健診誌，JAMHTS，No.1より転載）

\section{3. 歴代学術大会長名}

\begin{tabular}{|c|c|c|c|}
\hline 回 & 開催年 & 開催地 & 大会長 \\
\hline 1 & 1973 年 11 月 & 東京 & 樫田 \\
\hline 2 & 1974 年 6 月 & 東京 & 樫田 良精 \\
\hline 3 & 1975 年 1 月 & 東京 & 日野原重明 \\
\hline 4 & 1976 年 1 月 & 東京 & 藤間 弘行 \\
\hline 5 & 1977 年 1 月 & 大阪 & 佐藤 \\
\hline 6 & 1978 年 1 月 & 名古屋 & 高橋 春雄 \\
\hline 7 & 1979 年 1 月 & 東京 & 飯田 \\
\hline 8 & 1980 年 1 月 & 神戸 & 三木 \\
\hline 9 & 1981 年 10 月 & 東京 & 八坂 敏夫 \\
\hline 10 & 1982 年 1 月 & 水戸 & 大谷 育夫 \\
\hline 11 & 1983 年 1 月 & 大阪 & 宮川 定吉 \\
\hline 12 & 1984 年 1 月 & 東京 & 伊藤健次郎 \\
\hline 13 & 1985 年 1 月 & 横浜 & 土屋 章 \\
\hline 14 & 1986 年 1 月 & 東京 & 川合 \\
\hline 15 & 1987 年 1 月 & 静岡 & 鈴木 啓吾 \\
\hline 16 & 1988 年 1 月 & 東京 & 植田 理彦 \\
\hline 17 & 1989 年 2 月 & 岐阜 & 岩田 \\
\hline 18 & 1990 年 1 月 & 東京 & 清瀬 闊 \\
\hline 19 & 1991 年 2 月 & 大阪 & 清島啓治郎 \\
\hline 20 & 1992 年 1 月 & $\begin{array}{c}\text { 伊勢原 } \\
\text { (神奈川) }\end{array}$ & 日野原茂雄 \\
\hline 21 & 1993 年 1 月 & 別府 & 和田 秀夫 \\
\hline 22 & 1994 年 5 月 & 東京 & 田村 政紀 \\
\hline 23 & 1995 年 3 月 & 新潟 & 吉田 良二 \\
\hline 24 & 1996 年 1 月 & 東京 & 細野 清士 \\
\hline 25 & 1997 年 1 月 & 大阪 & 吉川 博通 \\
\hline 26 & 1998 年 2 月 & 東京 & 新谷 和夫 \\
\hline 27 & 1999 年 1 月 & 愛知 & 横井 正史 \\
\hline 28 & 2000 年 1 月 & 埼玉 & 萎沢 利行 \\
\hline 29 & 2001 年 1 月 & 熊本 & 小山 和作 \\
\hline 30 & 2002 年 1 月 & 東京 & 田村 政紀 \\
\hline 31 & 2003 年 1 月 & 横浜 & 松田 實 \\
\hline 32 & 2004 年 1 月 & 東京 & 小川 哲平 \\
\hline 33 & 2005 年 1 月 & 大阪 & 大橋 秀一 \\
\hline 34 & 2006 年 1 月 & 別府 & 和田 知益 \\
\hline
\end{tabular}

\section{4. 物故役員}

逝去された本学会歴代役員の中で，大きな功績を 残された 4 氏のことは特に記録にとどめておきた w。

1）故 樫田良精先生（1986 年逝去）（本学会会 長，創立時 1973 年 1986 年在任)

樫田先生は元東大医学部教授で, 日本で最初の中 央検查室を作られ, 検査会 $\mathrm{ME}$ 学会の重鎮でいらっ しゃった。本学会の発起人の一人であり, 本学会初 代学会会長に就任された。樫田先生の先見性とご熱 意が，総合健診をこの世に現し，本学会の産みの親 となった。そのご功績をたたえ, 樫田賞が優秀論文 賞となって現在も引き継がれている。また厳正な精 度管理サーベイや優良施設認定制度や，国際健診学 会への協力など, 今日の本学会の基礎を作られた。

2 ）故 藤間弘行先生（1993 年逝去）（元副会長） 本学会の設立発起人のお一人である。本学会設立 時は幹事，まもなく副会長になられて，日野原重明 先生とともに樫田会長を支えて本学会発展に大きな 功績を残された。特に日本病院会を通して, 総合健 診と健保連との健診契約の道を開かれたことは特筆 される。病を得て逝去されたことは，本学会発展に とっても惜しまれる。

3 ) 故 岩井喜典氏（1997 年逝去）(元監事)

元東芝メディカル社長で, 本学会設立発起人の一 人である。樫田先生に前後して，いち早くカイザー の AMHTS システムを見学し, 我が国に AMHTS シ ステムの導入を実現した。本学会の監查役を長く務 められたが, 本学会の創立にあたり果たされた功績 は特筆される。

4 ) 故 三輪卓爾先生（2006 年逝去）（元理事）

昭和 45 年（1970 年）に我が国で初めて自動化健 診がスタートしたのは, 東芝健診センターと PL 東 京健康管理センターであった。その東芝総合健診セ ンターの初代所長である。本学会創立以来, 幹事, 理事として活躍された。1967 年に初代会長の樫田 先生がKaiser財団の AMHTS を見学されたときに同 行された写真が記憶に新しい。八坂先生退任の後の 国際委員長として, 国際健診学会（IHEPA）の発展 に大きな貢献をされたことは特筆に価すると思う。

\section{5 . 忘れ得ぬ先達}

本学会の創立以来今日まで多くの諸先輩役員の先 生方に支えられて来たが, 本学会発展に顕著な貢献 をされた先生方については特にその功績を記してお きたい。 
1 ）岩塚 徹先生（元副会長）

本学会発起人のお一人であり, 総合健診の中心的 施設の一つである愛知県総合保健センター所長を長 く務められ, Kaiser 財団の世界初の AMHTS 1967 年に日本へ紹介した人としても知られている。樫田 会長のもとで学会理事, 日野原重明会長のもとで副 会長として学会発展に大きな貢献をされた。

2 ）八坂敏夫先生 (元理事, 国際委員長)

PL 健康管理センター設立の中心的役割を果たさ れた。東大で数学を修めた後, 医師ではないが医学 博士の学位をとり, 医学とコンピュータに精通した 特異な才能の持ち主であった。樫田良精会長のもと で, 本学会の理事となり, 学術に貢献されたが, と くに国際健診学会会長に就任した樫田会長を助け て, 海外の研究者との交流の道を開き, 今日の国際 健診学会（IHEPA）における日本の立場を築いた。 定年で第一線を退かれたのが惜しまれる。

3 ) 伊藤健次郎先生（元副会長）

東京医大健診センター所長であり, 本学会副会長 として岩塚徹先生とともに日野原重明学会会長を支 えて, 本学会の発展に貢献された。本学会が財政的 に苦しい中で, 総務担当副会長として学会誌発刊等 に努力された。突然の病いで退任されたが，かえす がえすも残念であった。

4 ）菅沼源二先生 (元理事)

本学会の創立以来の役員の一人である。検査の専 門家として本学会の精度管理委員および委員長を務 めていただいた。樫田良精会長, 日野原重明二代会 長の信頼厚く, 本学会がその時々に直面する問題解 決のため大きく貢献してこられた。第三代理事長を 拝命した私も支えていただいた。精度管理サーベイ の改革, 受診者統計の整備, 協栄生命破綻による学 会事務局の緊急移転, 山口学会事務局長退任による 事務局長緊急就任など, 学会運営の要々で助けられ たことは数知れない。とくに, 公正取引委員会の調 查を受けた責任をとるため理事, 学会事務局長も委 員もすべて退任されてしまったが, NPO 健康增進 事業支援協会理事長としてご支援いただいている。 本学会の歴史を思うとき菅沼先生を抜きに語れな い。

\section{6. 健康保険組合連合会（健保連）および日本病} 院会（日病）との関係

本学会は, 総合健診という予防医学を行う学問の 集団であると同時に, 学問を成立させるため施設会 員の施設が財政的に成り立たねばならないという負
担を負っている。本学会設立後しばらくの間, 各施 設は赤字経営で大変な苦労をされたと聞いている。

本学会創立時, すでに日本病院会では健康保険組 合連合会と 1 泊 2 日の人間ドック契約を結び，健康 保険組合の福利厚生の一環として, 年 1 回の宿泊 ドック受診者を受け入れていた。日本病院会の役員 でもあった藤間弘行先生のご尽力によって, 昭和 49 年（1974 年） 4 月から本学会が優良自動化健診（現 在の総合健診) 施設を健保組合からの受診者を受け 入れることができる指定施設として推薦する制度が スタートした。その際本学会は優良施設を日本病院 会へ推薦し, 健保連との指定契約は日本病院会が空 口になった。受診者を得る道として健保連との契約 が開かれたが，長い間健診当事者の総合健診が契約 者とならず，日本病院会に契約を代行してもらうと いう変則状態が今日まで続いてきた。本学会が日本 病院会が管轄する人間ドック学会に比べて力が弱 かった間は，何の疑問も問題も生じなかったが，本 学会が次第に発展してくるにつれて, 健保連との健 診指定契約を日本病院会に代行してもらっているこ とが，あたかも本学会が日本病院会および人間ドッ ク学会の金下組織であるかのような誤解と扱いを受 けるようになり，問題として顕在化してきた。

近時, 本学会の創立について,「日本病院会予防医 学委員会第 2 部会として創設された」とする文章を 目にしたが，本学会の創立については巻頭に記した とおり, 本学会設立発起人の先輩諸氏のご努力に よって日本病院会とは関係なく, 独自に創設された ものであることを改めてここに明記しておきたい。

健保連との指定契約や健診料金契約など重要な問 題はすべて日本病院会の臨床予防医学委員会で検討 掌握されてきた。人間ドック学会副会長であり臨床 予防医学委員会副委員長でもあった藤間先生が総合 健診代表の委員の形で, 日本病院会と本学会の仲介 役をして下さっていて連携が保たれていた。ところ が藤間先生が平成 5 年 (1993 年) に逝去されたため, 日本病院会と本学会のパイプが切れてしまい, 日本 病院会および健保連との諸々の件に, 日本総合健診 医学会の意見がまったく反映されないという状態に なってしまった。

本学会二代目会長に就任された日野原重明先生 は, 臨床予防医学委員会に総合健診代表が入ってい なくて，総合健診の意見が反映されないことを憂慮 されていた。日野原会長が臨床予防医学委員長で あった依田忠雄先生 (岡山日赤院長) と交渉され, 私 
(田村)が総合健診を代表して臨床予防医学委員に就 任した。後に日野原茂雄先生も委員に加わった。

臨床予防医学委員会に出席して分かったことは, 人間ドックや健診に関係する（料金も含めて）一切 のことがこの委員会で決められていること, 健保連 との契約は日本病院会が面倒見ているのだから, 総 合健診は日本病院会の方針に従ってもらいたいとい う厳然たる䨌囲気であった。

公正取引委員会の口頭注意があるまでは (平成 15 年 $(2003$ 年) ), 毎年健康保険組合連合会において, 臨床子防医学委員長と副委員長と健保連理事の間で 料金交渉が行われた。総合健診の料金交渉もあるの で，この席へ私も同席していた。総合健診は昭和 49 年（1974 年）に健保連との契約が始まって以来, 優 良施設が各施設の料金を申告し，健保連がこれを認 めるという形式をとっていたが，各施設の申告料金 はバラバラであった。一方日本病院会は統一料金契 約を行っていて, 保険点数に換算して $1 \sim 2$ 点の増 減をめぐって, 健保連の担当理事と臨床予防医学委 員長が激しい攻防を展開することがよくあった。料 金決定の厳しい攻め合いの現実を目にしていたが, 総合健診は対健保連となると, すべて日病の下に置 かれた形になっているため, 私から総合健診代表と して発言する機会がなかなか与えられなかった。同 時に, 臨床予防医学委員長と健保連理事の会話を聞 いていて, 日病にも健保連にも, 総合健診の特徵や 日病や全日病のドックと総合健診との違いが全く理 解されていないことが分かった。これは藤間先生が 抜けて数年間, 総合健診側の意見が全く反映されな かったことによるものと思われた。

健保連に総合健診の良さを知ってもらう必要性を 痛感した私は, 料金交渉を重ねて顔なじみになった 健保連幹部に, 総合健診の料金交渉を別途行う提案 や健保連とけんか腰で交渉するのはやめて, 総合健 診と共同研究の提案を行い, また勉強会への出席や 学術大会への健保連講演を依頼するなど, できる限 りの健保連との接触に努力した。平成 13 年（2001 年）には思い切って健保連に「健保連との健診契約 を日本病院会経由で行っているが, 総合健診が健保 連と直接契約するように改めるわけにいかないか」 と交涉した。時期尚早ということと日本病院会の同 意が得られていないということで，このときは拒否 された。その後も日本病院会と健保連へ様々の働き かけを続けていたが, 平成 15 年（2003 年）の公取 問題を機に事態は大きく動き，対健保連と対日病へ
働き続けて来たことの多くが実現した。昭和 49 年 （1974 年）に日本病院会経由で健保連との健診契約 ができて以来, 31 年にわたって日本病院会には本当 にお世話になった。改めて日病へお礼申し上げた い。今後はお互い独立した組織として大人のお付き 合いをする時が来た。しかし, 本学会の創立時に日 本病院会予防医学委員会第 2 部会として発足した等 という（人間ドック, Vol. 20, No. 1, 5〜6 p, 2005) 誤りだけは, 訂正してもらわねばならない事を創立 時役員の岩塚副会長, 稲田理事等の確認を得たの で,ここに重ねて記しておきたい。

\section{7. 総合健診施設協議会のこと}

平成元年（1989 年）の消費税導入時に, 健診施設 の経営責任を直接負っている施設長を代表して, 藤 間弘行先生, 土屋章先生と私の 3 人が発起人となり, 日野原重明会長の了解のもとで, 総合健診施設協議 会を組織した。消費税の問題が決着したので, 本家 の総合健診医学会の活動を全面的に支援することを 目的に, 土屋章先生を会長として施設協議会を存続 させることになった。

施設協議会設立時の総合健診医学会は, 学会財政 の厳しい状況で, 学会の各委員会活動や研究会が停 滞していた。施設協議会が学会の研究を支えるべし だということで, 土屋先生と一緒に厚生労働省へ施 設協の研究費の交渉によく出かけた。高齢者の健 診, 問診, 精度管理評価など, 次々テーマを決め予 算を獲得して研究を進めた。この一連の施設協の 行った研究成果は, 総合健診医学会本家の研究支援 の力となったことは間違いない。ただ会員施設の 1/4 しか所属していない施設協であるのに,「施設協 議会が頑張らねばいけない」という意識が, 施設協 の事務長さん方の間で妙に強くなってしまったこと が, 閉鎖的な集団を形成しそうになった。私が学会 理事長に就任した翌年の平成 10 年 (1998 年) 1 月の 第26回大会での事務長会開催を, 施設協会員施設の 事務長だけで行おうとしたため,「学術大会の事務 長会は本学会施設会員のすべての事務長の会であ り, 施設協の事務長会ではない。勘違いしては困 る」と説得して, ようやく全施設の事務長会として 開催したという一件があった。

施設協議会の進む方向が狂い出しそうであると気 付いた私は, 施設協の会員は元々学会の会員である ことから, 学会本体と施設協議会の一体化を図ろう と考え, 施設協会長の土屋先生に提案したが, 受け 入れられなかった。その後土屋先生が会長を退任さ 
れ，小山和作先生が施設協 2 代目会長に就任された。 土屋先生のもとでは私が会長代行副会長となってい たが, 私が総合健診医学会の理事長に就任したた め, 施設協の理事を退任した。小山先生が本学会理 事でいらっしゃる間は意思の疎通はとれたが，小山 先生が本学会理事を定年で退任された後, うまく交 流できなくなってしまった。小山和作先生が施設協 の会長のまま人間ドック学会理事に就任され, さら に人間ドック・健診機能評価機構の評価委員長に就 任されたため, 施設協の動きが本学会の動きとは逆 のことがあり，施設会員から質問や悩みが寄せられ るようになってしまった。「総合健診医学会の理事 長の施設も施設協の会員じゃないですか」との誤解 を招くのを避けるため, 平成 17 年 (2005 年) 9 月に 私の施設は施設協議会を退会した。総合健診医学会 の支えになろうということでスタートした施設協議 会であるが, リーダーが変われば活動方向も変わる のはやむを得ない。施設協議会はその後人間ドック 学会の傘下に入り, 現在は「人間ドック健診協会」 となっている。時の流れとしか言いようがない。

\section{8. 協栄生命事業団とのこと}

日本総合健診医学会の歴史を語るとき, 創立時か らしばらくは東芝総合健診センターにお世話になり (昭和 48 年 (1973 年) 〜昭和 60 年 (1985 年)), そ の後協栄生命健康事業団にお世話になった。協栄生 命は全国に 7 つ健診センターを持っていた。協栄 生命には学会事務局への支援と, 研究助成金の両面 で大変お世話になった。協栄生命のご配慮で本学会 事務局が協栄生命新宿ビル $7 \mathrm{~F}$ に入居させてもらっ たのは昭和 60 年 (1985 年) であった。7階ワンフロ アーを極めて低家賃で使わせていただいた。その 上, 毎年総合健診に対して 300 万円の協栄生命健康 事業団の研究助成金を出費して下さっていた。

本学会の会員数が伸び悩み, 学会運営の財政に苦 しんだとき, 協栄生命の支援によって本学会の運営 が維持できたことを思うと感謝に耐えない。

残念なことに協栄生命が倒産したため, 協栄生命 ビルからの学会事務局移転, 研究助成金の打ち切り など波乱にみまわれたが, 協栄生命からの支援の事 実は, 本学会の歴史に長く止められるべきものであ る。

9. 国際健診学会（IHEA 後の IHEPA）について 現在, 日本総合健診医学会は国際健診学会 (IHEPA) の中心的存在になっているが, 国際健診学 会の創立とその後の経緯については, 三輪卓爾先生
の「総合健診医学会に関する国際活動」(日自健誌, JMHTS, vol. 20, Supple., 1993）に詳しく述べられ ている。

国際健診学会が今日あるのは, ひとえに日野原重 明先生の熱意の賜物であることを記しておきたい。 平成 2 年（1990 年）の米国サンフランシスコでの IHEA 大会後, IHEA は極度の財政困難に陥った。サ ンディエゴ大会の次は, 英国の Bupa が担当して開 かれることになっていたが, Bupa が大会主宰を降 りてしまい，大会長の Last女史が Bupa をも退職し てしまった。当時 executive vice president で IHEA 本部の実質責任者であった Mr. Timken が，やむな くアメリカからスイスのジュネーブへ出張して, IHEA ジュネーブ大会を開催することになった。財 政状態も逼迫し, 本学会へも Seed Money の拠出の 要請があり，臨時に資金を送って，ようやくジュ ネーブ大会が開催された。

当時平理事ではあったがジュネーブ大会に三輪先 生とともに参加した私は，思い余って日野原重明先 生に「こんな財政的に成り立たない学会は, 一度止 めて作り直したらどうですか。IHEAなんかやめた らどうですか」と三輪先生と一緒に直訴した。日野 原先生は「日本の戦後の復興の大変なときに, アメ リカによって助けてもらって復興した。その恩は忘 れてはいけない。IHEAが苦しいときこそ，日本が 頑張って支えないといけない。今日本が IHEAから 手を引いたら IHEA は崩壊してしまう。日本に学会 は沢山あるが，日本が手を引いたらすぐつぶれるよ うな，日本が中心になっている学会は IHEA だけで ある。IHEA は絶対支えていかねばならない」と断 固としておっしゃった。

日野原先生の固い決意を知った私は思いを新たに したことであった。ジュネーブ大会で日野原重明先 生の IHEA 会長続投が決まり，日野原先生から私に IHEA 東京大会の大会長にとのご指名があった。

財政逼迫の IHEA の再生を考えてお引き受けし た。IHEA 東京大会を成功裏に開催できたのは, 日 野原先生のご熱意と, 三輪卓爾先生の強力なご支援 があったからこそのことであった。

IHEA 再生に貢献する決心をした私と三輪先生は 行動を起こした。東京大会開催前年の平成 5 年 (1993 年) に, IHEA 本部の Mr. Timken から 11 月 3 日から 6 日にワシントンでアメリカ情報学会 (SCAMC)の年次大会が開かれ, IHEAのアメリカ理 事の大半が集まるので, IHEAの臨時理事会を開き, 
東京大会の準備状況を話してもらいたい。SCAMC の Working Group Conference で IHEA 東京大会のア ナゥンスをやってほしいとの連絡が入ったので, IHEA 東京大会プログラム委員長をお願いした三輪 先生と一緒にワシントンへ赴いた。日本を発つ直前 に, Mr. Timken から「SCAMC の Conference Reception があるので, Halloween の仮装を用意してくる ように」との連絡が入った。三輪先生も私も Halloween の仮装の経験など全くなかったが，日本から参 加するのだから “サムライ”の姿をやろうと思い, 頭からすっぼりかぶるゴム製のチョンマゲ仮面と祭 りのハッピを用意した。ホテルで三輪先生と一緒に サムライ仮面をかぶってみて恥ずかしさでいっぱい になったが, “東京大会のため”と腹をくくって廊下 に出た。Halloween の Conference Reception 会場ま での間に廊下ですれちがう人が，びっくりして見て いた。ホールには 1,000 人ぐらいの参加者があり， そのうち仮装しているのは 30 人ぐらいであったが, IHEA ジュネーブ大会長であった Dr. Williams 夫妻 や Mr. Timken 夫妻は, 普通の服装で参加していた が，私たち 2 人の仮装を見て大喜びして下さった。 パーティ参加者に IHEA 東京大会の宣伝ビラを配っ た。この時の興奮を何かあるごとに思い出す。

IHEA 東京大会はいろんなドラマがあり, 奇跡的 とも言えるほど成功裹に開催できた。詳しい経過を 私ども自施設の年報「平成 5 年度健診成績報告書」 に記した。

IHEA が IHEPA となり, その後なんとか国際学会 として維持できているのは, 日野原重明先生の固い ご意志があってのことである。その後, 平成 15 年 (2003 年) 10 月の IHEPA アトランタ大会で, 私が IHEPA 会長に指名され, 平成 18 年（2006 年）1月 IHEPA 別府大会を主宰した。日野原重明先生が再 び IHEPA 会長になり, 来年 (2008 年) 10 月に IHEPA 北京大会が開催される。

\section{II. 平成 9 年（1997 年）1月の理事長就任から 平成 17 年 (2005年) 12 月 1 日の中間法人 への完全移行までの歴史}

\section{1. 三代目理事長に就任して, 最初に日本医学会 加盟を目標に掲げた}

私は平成 8 年 $(1996$ 年) 12 月の本学会理事会での 推挙を受け, 平成 9 年（1997 年） 1 月の本学会第 25 回大会における総会で日本総合健診医学会理事長に
就任した。就任して 1 年たった第 26 回大会での挨拶 の中で, 会員の皆さまに本学会の方向づけと目標を 提案した。

目標として揭げたのは「日本医学会に加盟を果た すこと」等であった。日本医学会入りを目指す目的 は次の 2 点であった。

1. 日本総合健診医学会が学問の会として正式に 認知されることになる。

2. 日本医学会に加盟している学会が作る認定医 制度協議会に加入することによって, 看板に 認定医もしくは専門医の広告が可能になる道 が開けそうである。

日本医学会加盟を実現するために, 日本医学会分 科会にふさわしい学会の内容となるよう整備する必 要があり, 10 年前の当時正会員が 620 名しかいな かったので, 1,000 名以上の会員数になるよう呼び かけた。また予防医学の学会にふさわしい学問的 デー夕を持つため, ICD-10に準拠した受診者統計 の提出をお願いした。平成 18 年 (2006 年) 7 月現在 の正会員数は 2,013 名, 受診者統計による日本総合 健診医学会会員施設への受診者は 190 万人を数えて いる。

日本医学会への加盟申請を毎年行っている。平成 18 年（2006 年） 7 月末で 9 回目の加盟申請を行った が, まだ加盟は実現していない。しかし英文学会誌 の発行, 施設や担当者のレベルアップを支えるため の各種研修会を開催し, 学問する学会としての基盤 は整備されつつある。

\section{2. 学会事務局の移転}

本学会が昭和 48 年 (1973 年) 11 月 18 日設立され たが, 事務局は東芝中央病院の敷地内にあった東芝 総合健診センターに置かれた。初代事務局長は逸見 正悦氏であった。昭和 60 年 (1985 年) 7 月から事務 局は協栄生命新宿ビル 7 階に移った。協栄生命のご 好意で, 会議用の室もお借りできた。逸見氏の定年 退職により, 平成 3 年（1991 年）事務局長は伊澤芳 雄氏に交代した。平成 11 年（1999 年）定年を迎え た伊澤氏に代わり，第三代事務局長に，東芝メディ カルから出向の形で山口操氏が就任した。

平成 13 年（2001 年）に協栄生命が破綻するとい う一大事が起こった。長い間本学会を支援して下 さっていた協栄生命健康事業団も消滅し, 協栄生命 ビルは外資系生命保険会社の持ち物となり, 莫大な 敷金と家賃を請求されることが分かり，とても払え ない金額であったので，賃貸契約期限の平成 13 年 
(2001 年) 7 月末までに, 急遽学会事務局を同ビルか ら退去させることにした。退去にあたっては，元通 りの室に復帰させねばならなかった。学会創立以来 28 年間の書類と備品の山を新しい学会事務局へ移 さねばならないが, 急に右から左へと室が確保でき るはずもなく，途方にくれた。ちょうど事務局長の 山口操氏が, 元の東芝メディカルサプライ社へ戻る こととなったため, 緊急対応として, NPO 健康増進 事業支援協会を設立し，その理事長に就任してい らっしゃった菅沼源二先生に頼み込んで, 学会事務 局長を兼任していただいた上に，新事務局が決まる まで菅沼先生の NPO 事務局へ学会の荷物を置いて いただくことにした。早く契約期限までに協栄生命 ビルから退去するため, 未整理の書類の山を段ボー ルに詰め込んでとにかく運び出した。NPO 事務局 の室いっぱいに天井まで届く段ボールの山に, 私も 菅沼先生も言葉を失った。あまりの酷さと NPO に 迷惑をかける状況を日野原重明先生にも見ていただ いた。この未整理の書類の山を，コッコッと開いて は整理して下さった菅沼源二先生にはお礼の言葉も ない。こうして, 本学会事務局は平成 13 年（2001 年) 8 月 1 日から NPO 健康增進事業支援協会に同居 させてもらうことになった。

本学会の激動は続いた。平成 15 年 (2003 年) 4 月 に本学会が公正取引委員会の調査を受けるという大 事件が発生した。結局罪にはならなかったが，9月 5 日「口頭注意」を受けた。この事件の責任を取る 形で，菅沼源二先生が事務局長を辞任することにな り, この件は理事長の私にとっても, 事務局長の菅 沼源二先生にとっても過酷なつらいできごとであっ た。

学会事務局も NPO にいつまでも居候しているわ けにもいかず, 場所を捜し, 渋谷区神山町の現在地 に新しい事務局を決めた。学会副理事長で総務担当 理事の萎沢利行先生にお願いして, 非常勤の事務局 長に就任していただいた。学会法人化と健保連と独 立して契約するという長年の念願が実現し, 平成 16 年 $(2004$ 年) 9 月 2 日に有限責任中間法人の認可を 受けた。将来学会が中間法人に完全移行するまでの 間, 任意団体としての学会と中間法人としての学会 が同居することとなった。中間法人としての学会に は, 健保連との連絡という重要な任務があるため, 中間法人の事務局長を常駐させる必要があった。学 会三役会と理事会にはかって, 法人事務局長の全国 公募を行ったが, 推薦も応募もなかった。健保連と
の健診契約の手前，法人の事務局長不在のまま放置 できず，困ったあげく私が所長をしている PL 東京 健康管理センターの平木尚司氏に事務局へ出向して もらうことになった。平成 17 年 (2005 年) 3 月理事 会で, 学会事務局長を平木尚司氏に一本化し今日に 至っている。

3. 全国各地区の施設長および事務長さん方との

懇談会を行う

学会理事長として, 日本医学会加盟を旗印にかか げ，加盟できる学会にふさわしい学会内容整備を行 うためには，全国核施設の施設長と事務長さん方と 膝を交えて話し合うのが一番必要なことと思い至 り, 平成 11 年（1999 年）から公取問題が起こる平 成 14 年（2002 年）まで足掛け 4 年間，学会事務局 長の菅沼源二先生と全国行脚をした。全国を 8 地区 (北海道, 東北, 関東, 北陸, 東海, 近畿, 中 - 四 国，九州）に分け，出かけた。私は施設長さん方と 懇談し，菅沼先生には事務長さん方と懇談していた だいた。平日は自施設で働き，土日に全国行脚に出 かけるというハードスケジュールであったが，懇談 会では本音を聞かせてもらい, 学会運営方針の理解 もしてもらった。どの地区にどんな人材がいらっ しゃるかも分かり，あらゆる面で非常に参考になっ た。公取問題発生によって，全国行脚を中断せざる を得なくなったのは残念なことではあった。

4. 公正取引委員会の口頭注意を受けて, 日本総 合健診医学会の法律遵守と再犯の防止について 学会方針の確認を行った

平成 15 年 $(2003$ 年) 4 月に本学会が公正取引委員 会の調查を受けるという本学会 32 年の歴史始まっ て以来，未曾有の事態が発生した。優良施設におけ る入札料金問題が発生し，本学会の倫理規定等に係 わる対応に対して独禁法違反の疑いありとのこと で, 平成 15 年 (2003 年) 4 月 14 日から数次にわた り，本学会が公正取引委員会の調查を受けた。

この調査に対して, 平成 15 年 (2003 年) 9 月 5 日 に公正取引委員会から出頭命令があり「口頭注意」 を受けた。このとき受けた注意に対して学会として 直ちに改善し, 全会員に対して今後の再発を防止す るための対応を行った。

すなわち，公正取引委員会の口頭注意を受けて， 日本総合健診医学会は 2 点の学術団体としての活動 の確認を行った。

1) 公正取引委員会から,「学会（事業者団体) は独占禁止違法に抵触する恐れのある行為を行って 
はならない」との注意を受けたことから，優良施設 に関する倫理規定の中の料金の規則に関する事項, 優良施設認定申請書の料金の規制等に関する事項, 施設調查表の健診料金の調査項目等，健診料金に関 する項目や規制に関する文言をすべて削除した。そ の上で「日本総合健診医学会は健診料金に関する問 題等法に抵触する恐れのある事項には一切関与せ ず，総合健診と予防医学の領域の学問に専念し，予 防医学としての質の保障と維持向上に専心努力す る」ことを学会の方針として明確化した。

具体的には

(1)学問する学会として, 日本医学会加盟への努力 を継続する

(2)予防医学としての質の向上のため, 総合健診医 学会独自の厳正な優良施設認定制度を継続し, 客観的な第三者評価を遂行するための総合健診 施設評価機構を発展させる

(3)健診の質の向上と信頼性確保のため，精度管理 や研修会をはじめ，学術的機能面をさらに発展 充実する

の 3 点を改めて挙げた。

2) いま一つの確認は

公正取引委員会による調査は, 総合健診医学会の 会員間に発生した事態に対する審判であるのに，当 事者ではない日本病院会と健保連にも公取の事情聴 取が行われるという大変なご迷惑をおかけしてし まったことを心からお詫び申し上げた。日本総合健 診医学会が健保連との契約当事者であるべきところ を，日本病院会に代行していただいてきたが故に， 日本病院会が公取の調査を受けてしまったというこ とを深く反省し，日本総合健診医学会理事会は「二 度と日本病院会, 健保連等関連団体にご迷惑をかけ ることのないよう，学術団体としての学術性と自立 （律）性」を確立し，「自分のことは自分で責任を持 つため，健保連との健診施設の指定契約を，日本総 合健診医学会が直接健保連と対応できるよう日本病 院会と健保連へお願いする」ことを決議した。

5. 人間ドック学会理事長 (日本病院会副会長)

奈良先生および日本病院会会長山本修三先生と 会談した

平成 16 年 $(2004$ 年) 4 月 27 日に奈良昌治先生と 会談した。会談では 3 点のことが話し合われた。

1）第 1 点は公取からの日本病院会への注意で, 日本病院会役員と総合健診医学会の役員の兼任を避 けるよう指示があったということで, 奈良先生から
総合健診医学会名誉理事長日野原重明先生の, 人間 ドック学会理事, 日本病院会人間ドック認定指定医 委員長からの退任, 田村の人間ドック学会理事およ び人間ドック認定指定委員会副委員長, 日本病院会 予防医学委員からの退任, 萎沢利行先生の人間ドッ ク学会理事からの退任要請があった。

2 ) 第 2 点は, 日本病院会と人間ドック学会が設 立準備を進めていて, 平成 19 年 (2007 年) 9 月から 実施する人間ドック・健診施設機能評価機構につい てであった。

総合健診医学会は 30 年の歴史を持つ優良施設認 定制度を行ってきている。聞くところによると，全 日病は独自の施設評価制度を続けるとのことであっ た。日本病院会の人間ドック・健診施設機能評価機 構は日本病院会所属の一泊人間ドック実施病院に対 する機能評価を行うこととし, 日病, 全日病, 総合 健診医学会の三者は, それぞれの施設機能評価を行 うことを認め合い，尊重し合うことに合意した。な お，将来それぞれの施設評価機構を一本化した方が 良いとなった時は, 検討するという将来への含みを 持たせることでも合意した。

3 ）第 3 点は健保連との契約体制の変更お願いの 件であった。

総合健診医学会の会員施設の入札問題に端を発し て, 日本病院会も公取の調查を受け, 口頭注意を受 けるという大変なご迷惑をかける結果となり, 誠に 申し訳なく改めてお詫び申し上げた。公取の事情聴 取を受けた際公取から，健保連と総合健診の契約を 行うにあたり, 当事者の総合健診医学会が契約者で なく, 日病が契約者となっている。しかも日病と総 合健診医学会の間に何の契約書もないという不自然 な関係であることを指摘された。日病が契約者と なって下さっていたために, 総合健診の料金問題で 日病も調査を受け, 口頭注意を受けるということに なってしまった。総合健診の総意として二度と日病 にご迷惑をかけないよう，自分たちのことは自分で 責任を持つ体制にしなくてはならないという理事会 決定の上で「日病に二度とご迷惑をかけないために, 健保連との総合健診の契約を総合健診医学会が直接 契約を行う体制にしたいと思います。よろしいで しょうか」と奈良先生に申し上げたところ，奈良先 生は「結構です。そうして下さい」とおっしゃった。 同席していた日本病院会の山口事務局長と中田課長 も異存なく了承された。

さらに確認のため「今年度 (平成 16 年度) の契約 
はすでに済んでいますので, 次年度(平成 17 年度)か らの契約を健保連と直接行えるよう，近々に健保連 へお願いに行ってきます。健保連には日病は了承済 みということで申し上げてよろしいですね」と念を 押したところ，奈良先生は「結構です。健保連とう まく交渉されて下さい」とおっしゃった。

日本病院会副会長で人間ドック学会理事長の奈良 昌治先生との会談で上記の合意を得たので, 平成 16 年 $(2004$ 年) 6 月 15 日日本病院会会長の山本修三先 生と会談した。

奈良先生との会談で合意した 3 点について，山本 先生は改めて日本病院会会長として了承して下さっ た。

一連の会談で, 総合健診医学会が健保連との契約 の当事者になることと，直接契約する体制に改める ことを健保連へお願いすることについて，日本病院 会と人間ドック学会の了承が得られた。

\section{6. 健康保険組合連合会椎名正樹理事, 町田忠昭}

\section{保健部長と会談}

健保連との総合健診の指定契約を総合健診医学会 が直接当事者として契約する体制に改めることと， そのことを健保連へお願いすることについて，日本 病院会および人間ドック学会の了承が得られたの で, 平成 16 年（2004 年） 6 月 25 日，日本総合健診 医学会理事長の田村が健保連へ参上し, 椎名理事, 町田保健部長と会談した。

健保連との契約を日本病院会に代行して行ってい ただくことになった歴史的背景を含め, 今日まで日 本病院会と健保連に大変お世話になってきた経過を 説明した。さらに昨年の公正取引委員会による口頭 注意をきっかけに，二度と日本病院会にご迷惑をか けないよう，自分のことは自分で責任を持つため, 健保連との契約を総合健診が自らの責任で行う体制 に改めることを日本病院会と人間ドック学会にお願 いし，了承を得たので，健保連に契約体制の変更を お願いしたく参上した旨申し上げた。

椎名理事は, 総合健診医学会が契約体制の変更を 願う事情を了解して下さった上で，2つの問題点の 指摘とアドバイスがあった。

1) 健保連は法人格を持たない任意団体と契約し た例がないので，日本総合健診医学会との契約にも 早急に法人格の取得が必要である。

2 ）例年健診の契約は秋から年末に行うが，10月 頃に健保連での三者会談を行うので，これに間に合 うように 10 月までに法人格を取ったらいかがです
か。

健保連から，任意団体とは契約した前例がないの で早急に法人格を取ること，それも今年 10 月までに 取るという明確なアドバイスを受けることができ た。

本学会ではかねてから，いつか法人化する日が来 ることを予測して法人化準備金を予算として計上 し, 総会承認を受けていたが, 健保連から明確なア ドバイスを受けて, 本学会の 30 年の歴史の中で初め て具体的な法人化へと動くことになった。

7. 日本総合健診医学会臨時評議員会および臨時 総会を開催し，本学会の法人化が承認され，有 限責任中間法人日本総合健診医学会を設立

理事会, 臨時評議員会, 臨時総会での法人設立の 決定を得て, 有限責任中間法人日本総合健診医学会 の設立登記に向けて手続きを進めた。平成 16 年 9 月 2 日付で法人の設立登記を完了し，9月 13 日に法人 の登記簿謄本を取得して, 法人設立登記の完了を確 認した。同時に学会事務局に法人専任の事務局長と 事務局員を配置した。本学会誌 (vol. 31, no. 6, 2004）に会告として法人設立完了の報告を行い, 平 成 16 年（2004 年） 9 月 17 日に健保連へ参上して, 椎名理事と町田保健部長に本学会の法人登記簿謄本 を提出し，法人設立完了と法人事務局体制の確立を 報告した。

本学会の法人設立を受けて, 平成 16 年 (2004 年) 10 月 28 日 (木)に健保連において「健診事業に関する 意見交換会」が開催され, 晴れて総合健診が独立し た団体として出席した。昨年度までは日本病院会の 一員としてしか出席を認められなかったが，今年か らは独立団体として認められての出席であったの で, 本学会 31 年の歴史の中の画期的なできごとで あった。本学会理事長に就任して揭げた目標の一つ が，会員の皆さまの絶大なご支援とご協力によって 実現した。

当日の出席は下記のメンバーであった。（敬称略）

奈良 昌治, 笹森 典雄 (日本病院会兼人間ドッ ク学会)

田村 政紀, 平木 尚司 (日本総合健診医学会)

太田宏, 小林 弘治(全日本病院協会)

対馬 忠昭, 椎名 正樹, 町田 忠昭, 伊藤

隆一(健保連)

この意見交換会の席上，健保連から総合健診との 指定契約を新たに中間法人日本総合健診医学会と結 ぶことが発表された。 


\section{8. 法人化に伴って新たな展開一厚生労働省の認} める広告規制緩和対象の総合健診専門医制度

健診医学を推進するためには，学会として学問的 業績を上げ，それを積み重ねていくことが一番大事 なことであるが，それには学会会員が所属する施設 が経営的に安定していることが必要である。経営安 定の最大の要因は，受診者を多く獲得できるかどう かである。そのためには「この施設は安心して健診 を受けていい施設なのだ」という目印がどうしても 必要だが，医療法によって広告が規制されているた め，世間様へ目印を提供できないでいることは，す べての施設長や事務長さん方の経営上の悩みであ る。私は医学雑誌の取材を受けるたびに「国民の誰 でもすぐ分かる健診を受けてよい施設の目印があり ますか？」との質問を受け続けてきた。現在のとこ ろ誰にでも分かる目印はない。本学会の優良施設認 定マークも外の看板に掲示できない。日病・人間 ドック学会の指定も, 全日本病院協会の認定も同様 に外の看板に広告できない。

私が本学会理事長に就任して, この広告規制を突 破する道を懸命に探していたころ, 日本医学会に加 盟する学会が認定制度協議会を作っており，「この 協議会に加入した学会に将来広告の道が開かれるら しい」との情報に接した。学問の会としての認知を 受けることと, 広告の規制緩和の認可を受けて各施 設の経営安定化を図りたいと念願し, 日本医学会加 盟入りの努力を続けてきた。毎年 7 月末日期限で提 出する日本医学会新規加盟申請書は 9 年続いている が，まだ加盟は実現していない。

ところが，世の中の規制緩和の動きとともに，中 間法人日本専門医認定制機構（認定医制度協議会が 後に法人化した）とは関係なく, 厚生労働省が直接 一定の基準を満たした学会の医師について, 専門医 の広告を行えるよう規制緩和を平成 14 年 (2002 年) 4 月 1 日から施行を開始した (厚生労働省告示第 158 号, 厚生労働省告示第 159 号)。

この法律によって, 学会が学問としての内容を整 え, 厳格な専門医認定制度と認定試験の実施を行え ば, 日本医学会入りとは関係なく, 広告規制緩和対 象の専門医を認可されることになった。内容整備の 第 1 の条件が「学術団体として法人格を有すること, 会員数が 1000 人以上であり, かつその 8 割以上が医 師であること」であることから, 本学会が法人格を 取得したことによって,「国（厚生労働省）が認可 する専門医の認可を受け看板に広告できる」道が開
けてきた。

平成 16 年（2004 年）9月 14 日の本学会理事会に おいて，本学会が将来の広告規制緩和の認可を受け るべく専門医制度を立ち上げることが機関決定さ れ，専門医制度準備委員会（吉田勝美委員長，小川 哲平副委員長）が発足した。専門医制度準備委員会 が活動を開始する一方, 厚生労働省との接触が始 まった。

厚労省の認可の諸々の条件の一つに「資格の認定 に際して 5 年以上の研修の受講を条件としているこ と」がある。日本病院会・人間ドック学会と共同で 5 年間「人間ドック認定指定医」制度を推進してき たことを実績として活かしたいと思い厚労省に接触 したところ, 残念なことに「人間ドック認定指定医」 は資格認定の厳格な試験もなく, 学術大会と研修会 に参加すれば取得できるものであるため，「人間 ドック認定指定医」を厚労省の専門医認可に活かす ことができないと判明した。

平成 16 年（2004 年） 12 月 8 日の本学会理事会で 厳正な条件をクリアーした専門医制度のスタートを めざして, 日本総合健診医学会専門医制度の本委員 会を立ち上げ，日野原重明先生に委員長就任をお願 いし, 私が副委員長に就き, 平成 16 年（2004 年） 12 月 10 日に第 1 回専門医制度委員会を行う一方日 本総合健診医学会として, 日本病院会・人間ドック 学会に対し, 人間ドック認定指定医の共同事業を解 消する旨の機関決定を平成 16 年 12 月 9 日付で正式 に通告した。

会員の皆さまの絶大なご支援によって, 平成 17 年 (2005 年) 6 月 5 日 (日)に第 1 回総合健診専門医試験 を実施した。あわせてコメディカルスタッフの総合 健診指導士認定の第 1 回試験も行われた。総合健診 の新しい展開の時を迎えた。

9. 総合健診専門医制度と並行してコメディカル スタッフの総合健診指導士ならびに一般事務職 の総合健診業務管理士認定制度のスタート

健診が医療である限り，医師の働きが中心になる のは間違いないが, 総合健診というチーム医療を円 滑に行うには, コメディカルスタッフ（保健師, 看 護師，検查技師，放射線技師，栄養士等）の役割は 大きい，また，予約受付やデー夕管理などを含め医 療行為の周辺を務める一般事務職の人の働きも重要 である。総合健診の質を高め, 顧客満足を得るため にも，専門職だけでなく指導士および業務管理士の 認定制度も不可欠との結論から，本学会は総合健診 
専門医制度と総合健診指導士認定制度をスタートさ せ，平成 17 年 $(2005$ 年) 6 月 5 日に専門医ならびに 指導士の第 1 回認定試験を行った。

\section{III. 本学会の今後の展望}

平成 17 年 $(2005$ 年) 7 月 22 日の本学会臨時総会 において, 平成 17 年 (2005 年) 11 月 30 日で任意団 体としての総合健診医学会を解散し, 12 月 1 日付で すべてを有限責任中間法人日本総合健診医学会へ移 行することが決まった。形, 内容ともに新しい総合 健診医学会へ脱皮の時を迎えた。

今後中間法人日本総合健診医学会としては, 学問 の充実をはかり，日本医学会入りを引き続き目指し ていく。学会誌や学術大会および各種研修会の充 実，ICD-10に準拠した受診者統計の充実が大きく 物を言うに違いない。

総合健診が社会的認証を得る具体像として, 厚生 労働省の「広告の規制緩和対象専門医」の認可をど うしても獲得したい。そのための専門医制度の充実 に併せて, 総合健診指導士ならびに業務管理士認定 を進め, 総合健診の質の向上と保証をはかっていく
必要がある。

本学会は 30 年にわたって厳しい優良認定審査を 行ってきたが, 客観的にみれば仲間同士の内部評価 である。平成 18 年（2006 年）から人間ドック学会 がスタートさせる人間ドック・健診機能評価機構も 仲間内の評価であり, 全日病の優良認定も然りであ る。今や社会は仲間内での評価だけでは認めず，第 三者 (外部) 評価が要求される時代となった。この 時代の趨勢をいち早く感じ取った本学会では, 日本 総合健診医学会が産みの親になって, 今年平成 18 年 (2006 年) 9 月に, 有限責任中間法人「健康評価施設 査定機構」を設立する。完全な第三者性を保つため, 総合健診, 人間ドック学会, 全日病のいずれにも属 さない学識者の中から開原成允先生に理事長就任を お願いし, 目下動き始めたところである。総合健診 は元より人間ドック学会も全日病もそれぞれの内部 評価に加えて, この査定機構の外部評価が開始さ れ, 予防医学の質の向上とその保証のため, 画期的 な働きをするようになると思っている。

特定健診と特定保健指導の開始も間近に迫ってい るだけに, 総合健診医学会がより良い健診を提供し て, 社会に貢献したいと願うものである。 